Galip Zihni Sanus · Taner Tanriverdi

Ali Metin Kafadar · Mustafa Onur Ulu • Mustafa Uzan

\title{
Use of Cortoss for reconstruction of anterior cranial base: a preliminary clinical experience
}

Published online: 27 October 2005

(C) Springer-Verlag 2005

Keywords Cerebrospinal fluid fistula $\cdot$ Cortoss $\cdot$

Methacrylate $\cdot$ Skull base reconstruction

\section{Eur J Plast Surg (2004) 27:371-377}

The references appeared without the numbers corresponding to the citations in the text. The correct reference list is given here.

\section{References}

1. Badie B, Preston JK, Hartig GK (2000) Use of titanium mesh for reconstruction of large anterior cranial base defects. J Neurosurg 93:711-714

2. Bowman CN, Peppas NA (1991) Coupling kinetics and volume relaxation during polymerizations of multiacrylates and multimethacrylates. Macromolecules 24:1914-1920

3. Bronson JG (2003) Tissue transplantation and engineering: what is happening? Orthop Technol Rev 5(5). http://www.orthopedictechreview.com

4. Costantino PD, Friedman CD, Jones K, Chow LC, Sisson GA (1992) Experimental hydroxyapatite cement cranioplasty. Plast Reconstr Surg 90:174-185

5. Costantino PD, Friedman CD, Jones K, Chow LC, Pelzer HJ, Sisson GA (1999) Hydroxyapatite cement, I: basic chemistry and histologic properties. Arch Otolaryngol Head Neck Surg 117:379-384

6. Costantino PD, Chaplin JM, Wolpoe ME et al. (2000) Applications of fast-setting hydroxyapatite cement: cranioplasty. Otolaryngol Head Neck Surg 123:409-412

The online version of the original article can be found at http:// dx.doi.org/10.1007/s00238-004-0711-1

G. Z. Sanus $(\bowtie) \cdot$ T. Tanriverdi · A. M. Kafadar

M. O. Ulu · M. Uzan

Department of Neurosurgery, Istanbul University Cerrahpasa

Medical Faculty, P.K. 16, Cerrahpasa, Istanbul, 34301, Turkey

E-mail: sanus@istanbul.edu.tr

Tel.: + 90-212-4143427

Fax: + 90-212-4143427

7. Costantino PD, Hiltzik DH, Sen C et al. (2001) Sphenoethmoid cerebrospinal fluid leak repair with hydroxyapatite cement. Arch Otolaryngol Head Neck Surg 127:588-593

8. Deramond H, Depriester C, Galibert P, Le Gars D (1998) Percutaneous vertebroplasty with polymethylmethacrylate, technique, indications, and results. Radiol Clin N Am 36:533546

9. Erbe EM, Clineff TD, Gualtieri G (2001) Comparison of a new bisphenol-a-glycidyl dimethacrylate-based cortical bone void filler polymethyl methacrylate. Eur Spine J 10:S147-S152

10. Goel A, Gupta S (2000) Reconstruction of the skull base: a review of personal technique. Neurol India 48:208-215

11. Jackson IT, Adham NM, Marsh WR (1986) Use of the galea frontalis myofacial flap in craniofacial surgery. Plast Reconstr Surg 77:905-910

12. Jones NF, Sekar LN, Schramm VL (1986) Free rectus abdominis muscle flap reconstruction of the middle and posterior cranial base. Plast Reconstr Surg 78:471-477

13. Kawanabe K, Tamura J, Yamamuro T, Nakamura T, Kokubo T, Yoshihara S (1993) A new bioactive bone cement consisting of bis-GMA resin and bioactive glass powder. J Appl Biomater 4:135-141

14. Kawaura M, Nameki H, Fujii M, Kanzaki J (1997) Use of vertical median forehead flap in the reconstruction of the anterior skull base: report of two cases. Auris Nasus Larynx 24:379-383

15. Kobayashi M, Nakamura T, Tamura J, Kikutani T, Nishiguchi S, Mousa WF, Takahashi M, Kokubo T (1999) Osteoconductivity and bone-bonding strength of high- and low-viscous bioactive bone cements. J Biomed Mater Res (Appl Biometer) 48:265-276

16. Krishman KG, Winkler PA, Müller A, Grevers G, Steiger HJ (2000) Closure of recurrent frontal skull base defects with vascularized flaps: a technical report. Acta Neurochir (Wien) 142:1353-1358

17. Mathur K, Tatum SA, Kellman RM (2003) Carbonated apatite and hydroxyapatite in craniofacial reconstruction. Arch Facial Plast Surg 5:379-383

18. Mori K, Nakajima M, Maeda M (2003) Simple reconstruction of frontal sinus opened during craniotomy using small autogeneous bone piece: technical note. Surg Neurol 60:326-328

19. Pomrink GJ, DiCicco MP, Clineff TD, Erbe EM (2003) Evaluation of the reaction kinetics of Cortoss, a thermoset cortical bone void filler. Biomaterials 24:1023-1031

20. Price JC, Loury M, Carson B, et al. (1998) The pericranial flap for reconstruction of anterior skull base defects. Laryngoscope 98:1159-1164

21. Ross DA, Marentette LJ, Thompson G, Haller J (1999) Use of bone cement to prevent cerebrospinal fluid leakage through the frontal sinus: technical report. Neurosurgery 45:401-403 
22. Senyuva C, Yucel A, Okur I, Cansız H, Sanus GZ (1996) Free rectus abdominis muscle flap for the treatment of complications after neurosurgical procedures. J Craniofac Surg 7(4):317-321

23. Shindo ML, Costantino PD, Friedman CD, Chow JC (1993) Facial skeletal augmentation using hydroxyapatite cement. Arch Otolaryngol Head Neck Surg 119:185-190
24. Weissman JL, Synderman CH, Hirsch BE (1996) Hydroxyapatite cement to repair skull base defects: radiologic appearance. Am J Neuroradiol 17:1569-1574

25. Yamamuro T, Nakamura T, Iida H, Kawanabe K, Matsuda Y, Ido K, Tamura J, Senaha Y (1998) Development of bioactive bone cement and its clinical applications. Biomaterials 19:14791482 